\title{
The Sociology of Pierre Bourdieu: theoretical potential for the subfield of nursing
}

\author{
A Sociologia de Pierre Bourdieu: potencialidade teórica para o subcampo da enfermagem \\ La Sociología de Pierre Bourdieu: potencialidad teórica para el subcampo de la enfermería
}

\section{Deise Ferreira Souza', Zenith Rosa Silvino'}

'Universidade Federal Fluminense. Niterói, Rio de Janeiro, Brazil.

How to cite this article:

Souza DF, Silvino ZR. The Sociology of Pierre Bourdieu: theoretical potential for the subfield of nursing. Rev Bras Enferm [Internet]. 2018;71(4):2055-9. DOI: http://dx.doi.org/10.1590/0034-7167-2016-0505

Submission: 10-18-2016 Approval: 07-09-2017

\begin{abstract}
Objective: to approach the basic conceptions of Pierre Bourdieu's sociology and its articulation with the subfield of nursing by focusing on managerial aspects. Method: reflections are based on the concepts of field, habitus, capital and symbolic power applied to the subfield of nursing by favoring the understanding of organizational dynamics and its agents. Result: health institutions are living structures in the adverse social world where nursing agents' interests express their way of thinking and acting according to the place they occupy in the organization. These spaces of fight and symbolic violence tend to inculcate ideologies that meet these agents' interests. Final Considerations: The proposition theory is fruitful to reflect the practice of management by unveiling the relationships and role that organizations establish about their agents. She warns about the possibility of seeing changes in the subfield of nursing.

Descriptors: Sociology; Nursing; Professional Practice; Organizations; Organization and Administration.
\end{abstract}

\section{RESUMO}

Objetivo: abordar as concepções basilares da Sociologia de Pierre Bourdieu e sua articulação com o subcampo da enfermagem, com enfoque nos aspectos gerenciais. Método: as reflexões se pautam nos conceitos de campo, habitus, capital e poder simbólico aplicados ao subcampo da enfermagem, favorecendo a compreensão da dinâmica organizacional e dos seus agentes. Resultado: As instituições de saúde são estruturas vivas inseridas no mundo social adverso, onde os interesses dos agentes da enfermagem expressam sua forma de pensar e agir de acordo com o lugar que ocupam na organização. São espaços de luta e violência simbólica que tendem à inculcação de ideologias que atendam seus interesses. Considerações finais: A proposição teórica bourdieusiana é fecunda para refletir a prática da gestão ao desvelar as relações e o papel que as organizações estabelecem sobre seus agentes. Ela alerta sobre a possibilidade de se vislumbrar mudanças no subcampo da enfermagem.

Descritores: Sociologia; Enfermagem; Prática Profissional; Organizações; Organização e Administração.

\section{RESUMEN}

Objetivo: Abordar las concepciones basilares de la Sociología de Pierre Bourdieu y su articulación con el subcampo de la enfermería, con enfoque en los aspectos gerenciales. Método: Las reflexiones se basan en los conceptos de campo, habitus, capital y poder simbólico aplicados al subcampo de la enfermería, favoreciendo la comprensión de la dinámica organizacional y sus agentes. Resultado: Las instituciones de salud son estructuras vivas en el mundo social adverso, donde los intereses de los agentes de la enfermería expresan su forma de pensar y actuar de acuerdo con el lugar que ocupan en la organización. Son espacios de lucha y violencia simbólica que tienden a la inculcación de ideologías que atiendan sus intereses. Consideraciones finales: La proposición teórica de Bourdieu es fecunda para reflejar la práctica de la gestión al desvelar las relaciones y el papel que las organizaciones establecen sobre sus agentes. Ella alerta sobre la posibilidad de vislumbrar cambios en el subcampo de la enfermería.

Descriptores: Sociología; Enfermería; Práctica Profesional; Organizaciones; Organización y Administración. 


\section{INTRODUCTION}

Between the 1960s and 1980s, the philosopher Pierre Bourdieu made a strong contribution to the formation of $20^{\text {th }}$ century sociological thought. Throughout his life, he developed studies of social, cultural and historical phenomena that were employed in several areas of knowledge. He explored different objects and problems, from the tribal society of Kabyle to the genesis of the state, which creates and imposes the means of division. He then went through various fields of knowledge and discussed topics such as education, culture, art, media, linguistics and politics(1).

In the late 1950s, in his early works on Kabyle society, he made conceptual reflections on the society-space relationship. He observed the spatial organization of symbolic oppositions, the division of tasks and their relation to society. He worked the relationship between physical space and social space by analyzing the social effect of space and discussing how the colonial system interfered in the structures and deculturation of this people ${ }^{(2)}$.

Later, he focused his critical eye on academic knowledge and the role of sociology in the face of society and sociology itself by questioning the formation of the sociologist as a censor and holder of a real discourse on the social world. Thus, sociology could not forget that "its belonging to the social world presents itself as a problem of knowledge, never totally dissociable from the practices and practical tasks resulting from that belonging"(1).

Bourdieu admits the existence of objective structures in the social world that can direct or coerce agents' actions and representations. However, agents can transform or conserve such structures, or at least desire changes. It is a fact that such structures are socially constructed, agents incorporate the social structure and at the same time, produce, legitimize, and reproduce it. In this sense, Bourdieu rejects the dichotomy subjectivism/objectivism, since social relationships happen in a dialectical relationship ${ }^{(1)}$.

His theory is constituted by a set of basic concepts such as habitus, field and capital (social, cultural, economic and symbolic), and symbolic power. The social world is a space of struggle, violence and symbolic power that aim at the inculcation of ideologies by favoring the maintenance of the place of power. These conceptions of Bourdieu are employed in various fields of knowledge, since social practices are structured and have the characteristic properties of the social position of those producing them. Thus, "[...] the position occupied in the social space, that is, in the distribution structure of different types of capital, which are also weapons, commands the representations of that space and the positions taken in the fights to preserve it or transform it"(3).

These fundamentals are directly included in the subfield of administration involving the formulation of administrative theories that in turn design the organization, establish the process and division of labor, relationships of subordination and power in institutions, performance standards, and consequently outline the management models seized by nurses and other professionals in professional practice.

The health field consists of several disciplines and areas of knowledge forming its subfields or subsystems. In the subfield of nursing, there can be several grasps of Bourdieu's sociology concepts, given the large dimension involving nurses' actions (agents), whether of care, teaching, direction of health institutions, research, consulting or political nature, among others. On the other hand, nurses establish interaction with the nursing team, other health professionals or professionals from human and organizational sciences fields. While producer agents of a service, they are also included in simple or complex organizations with an own structure and culture, and establish the norms permeating the organizational body work.

Therefore, there is a range of reflection and interpretation possibilities of the nursing subfield phenomena. This article proposes to present a reflection on contemporary perceptions of the social sciences by using the sociology of Pierre Bourdieu and his conceptions of habitus, field, capital and symbolic power applied to the subfield of nursing. It was taken into account the scarcity of health field research addressing this theoretical contribution, especially when considering the managerial and organizational perspective.

This proposition enables the discussion of the dynamics determining the organizational routine and the actions of its agents, not only from the foundation of administration theories, but under a new theoretical contribution. Bourdieu presents an analysis of phenomena such as reproduction, logic of domination and implications involving the symbolic violence that organizational structures exercise on their agents from a socio-historical perspective. Furthermore, it points to the possibility that its agents will subvert this paradigm from the critical and participant spirit.

\section{ARTICULATION OF PIERRE BOURDIEU'S CONCEPTIONS WITH NURSING MANAGEMENT}

There is a direct relationship between text and context, an intermediate universe that Bourdieu calls the field where "are inserted the agents and institutions that produce, reproduce or diffuse" art, literature or science. Thus we have the artistic field, the literary field and the scientific field ${ }^{(4)}$.

The health field uses scientific knowledge from different fields. The nursing subfield in particular, takes on the knowledge of biological, human and social sciences, of information technology, administration and education, among others. In professional practice, this knowledge is applicable in activities related to care itself. However, the knowledge of administration subfield gains prominence in care management or in the management of services or organizations in different scenarios. It should also be considered that nursing is inserted in institutions in charge of teaching, assistance, production and circulation of knowledge, where the administration discipline also has relevant space and is transversal throughout professional training.

Administration emerged as a social science that systematized management practices from the beginning of $20^{\text {th }}$ century. Initially, its focus was the search for efficiency of factory workers. Since then, it has been accompanying and revolutionizing the organizational world. A priori, it involved the organization in a prescriptive and normative approach in the administrative process of planning, organizing, directing and controlling. Later on, the aim was understanding people as partners and protagonists in the process of producing goods and services. The path of administration continued by bringing for itself the conceptions of sociology, organizational psychology and systems theory. By looking at the horizon of a globalized world and the information age, the science of administration began to understand and propose ways that would account for challenges 
of complexity, rapid transformations and uncertainties of the changing and unpredictable world.

The managerial standard of institutions managers was based on one or more references of the administration field in order to serve the interests and assumptions of organizations within a context of time. These paradigms have emerged in the search to meet the internal and external demands of organizations. Managers usually seek change from crises. From the need for new directions, emerge new managerial models that replace the previous one or complement one another. Even though these seem ambiguous, they intertwine or juxtapose in the proposition of setting another pace to institutional dynamics.

The nursing subfield was shaped in the light of its history and of political, economic and social changes that occurred in the country. As when management models were adopted in public and private health organizations in order to have a better response to their needs. In this sense, these models incorporated over time are not devoid of scientific content neither random, and were not born by chance.

Health institutions are living structures inserted in the adverse and contradictory social world, where the interests of field and subfields (subsystems) agents are closely linked to their place in the organization. Bourdieu admits the existence of these objective structures in the social world, which can direct or coerce individuals' actions and representations. On the other hand, there is a movement dialecticity of these agents that can conserve or transform such structures ${ }^{(1)}$.

There must be attention to contextualization in the subfield of nursing and the means of fight against the effects of naturalization and the simplistic and dogmatic look of what appears or is presented. In this understanding, we should refer to the past that constituted nursing not only as a means of describing it, but as a way of making contact with the event and, through the art of thinking, reflect the present that is intimately connected to us, but can present us as invisible. This fact makes us emphasize that fields and subfields have historically built a certain autonomy, and have particular characteristics with their conflicts, alliances, commitments and contradictions. That is, they have rules of coexistence in disputes and interests permeating their agents' relations ${ }^{(4)}$.

In the constant fight between classes of a society, there is the place of power and, when focusing on management, the subfield of nursing is no different. In order to maintain power, its holders defend their ideologies and aim to demonstrate their private interests represent those of the collective, which already characterizes symbolic violence. It is a hidden and concealed power that seeks to ensure domination. For Bourdieu, this is the symbolic power, that is, 'the invisible power that can only be exercised with the complicity of those who do not want to know they are subject to it, or even that they exercise it"(5).

Symbolic systems can only exert a structuring power because they are structured. This structure referred by Bourdieu concerns the symbols that bring the intention of making effective social integration, which in turn contributes to the formation of a consensus on reality and facilitates the reproduction of the social order ${ }^{(5)}$.

In health institutions, can be identified social relations historically constructed by the subfield agents constituting them, and who establish themselves in almost always contradictory dynamics, but not devoid of meanings. In order to understand its readings, it is necessary to recognize its origin, i.e., the socialhistorical path of each subsystem forming the health field, as well as its beliefs and the collective values produced in that field.

It is intriguing to look at the various dimensions in the social field of health and the nursing subfield in particular. Especially by considering that nurses guide their practice through 'regular behaviors' or the 'regularity of conducts' established institutionally. There must be an understanding that health institutions are structures socially built by their agents, and also regulate these agents' actions. In other words, organizations define the norms, values and competencies that must be internalized by their agents. This brings us to the habitus, understood by Bourdieu as the schemes of action and thought of the dominating or dominated agents. Thus, agents think, act and have the capacity to transform themselves and behave in a certain way according to circumstances ${ }^{(6)}$. In the organizational social space, the managerial habitus of nurses is oriented to the acquisition of prestige and recognition of their peers in order to ensure the institutionally desired authority.

In the social management practice, the managerial habitus represents the managers' action plan constructed from their knowledge and experience gained in the social space of training institutions and the organization where they are inserted. Thus, the subfield of nursing is imbricated in itself by considering its historicity in the health field context and in institutions where its actions are performed.

The process of acquiring the cultural capital invested by nurses contributes to the construction of their technical and administrative knowledge, of teaching and research, and also favors their political action. These knowledge types grant competencies that subsidize the agents' habitus in different organizational contexts. Therefore, the habitus is explicit in relationships with client and family, and with health agents in actions of caring, management of the team and services constituting the organizational structure of institutions. It is a north for understanding the power relationships established between dominant and dominated agents, and the symbolic power permeating these relations.

Bourdieu emphasizes that relationships of domination and the construction of worldviews surround the social dynamics practice, and individuals incorporate the social structure in which they live by legitimizing or reproducing $i^{(3)}$. Thus, we are, think and act as products of life in society and producers of social practices, either by confronting or confirming them. He considers the existence of the social universe under two articulated pillars: objectively, the 'field', and subjectively the 'habitus'. That is, there is a dialectical historical relation between the socially acquired individual conducts (habitus) of agents, and the objective structures or 'fields' of relationships between agents in different positions and empowerment ${ }^{(5)}$.

The social field is an objectively structured space of relations between its agents, who occupy different positions according to the unequal distribution of symbolic resources, that is, of multiple capitals ${ }^{(6)}$. Therefore, the fields are niches of confrontation of individuals' activity from where representations are legitimized. In this sense, Bourdieu "never compared a field to a game of blind forces [...] there are real and very different possibilities of transformation depending on the position occupied"(1). 
The fields and subfields are constituted of an own structure, and in a certain way, are autonomous in relation to the others, but differentiated by the type of capital: economic, cultural, and social. This fact is perceptible in the health field when observing the relationships between doctor and nurse. Although in the health organization there may be cooperation between these professionals, there are also conflicts over authority and power monopoly, because historically, doctors have legitimate authority to act and speak on behalf of this field ${ }^{(7)}$. Bourdieu uses the field of power terminology to designate "the relationships of force between the social positions that guarantee to their occupants a sufficient quantum of social force - or of capital - so they have the possibility to enter in fights for power monopoly"(5). Therefore, in the field are established conflicts, and fights for obtaining the symbolic power that produces and confirms meanings, and where values are validated and accepted by common sense. The habitus and the code of social acceptance are formed in it.

In the nursing subfield, the managerial habitus translates the constantly evolving references or models of management. They result from the complex interaction involving reflections that generate new practices stemming from social and political forces of each era that are aimed at achieving the effectiveness of a service or production sector. The insertion of a new model does not mean the extinction of previous models. In this way, "many people have taken hold of the beliefs and premises they had developed under the old model and continued to employ it to make their decisions"(8).

The concept of habitus discusses the capacity that individuals' feelings, thoughts and actions incorporate a particular social structure. The capital represents the accumulation of forces the individual can achieve in the field. Bourdieu and Passeron refer to the habitus as subjectively internalized symbolic schemes as a function of social living. They are forms of generation and organization of the practical activity of individual agents, which take the form of mental and bodily dispositions, socially acquired ways of acting, thinking, feeling, perceiving, interpreting, classifying and evaluating ${ }^{(9)}$. Therefore, habitus addresses the schemes, the capacity that agents' feelings, thoughts and actions incorporate a certain social structure.

Thus, conducts and decision making are a great challenge experienced in daily life. The same happens when agents occupy their positions, which is a symbolic power by itself, and they often face clashes and reactions. In most times, we think about how we should act, but there is not always time for reflection on how we react. Agents of a field or subfield have common interests and establish some complicity, although this is not always explicit. At some point, they may be in different positions: dominant or dominated. Assuming that institutions establish patterns of behavior and attitudes among social agents within them, and that such patterns and attitudes are sustained by power relations, nothing happens by itself without the existence of crises and resistances.

In the subfield of nursing, nurses lead their team, but at the same time, they are subordinate to another agent within the organizational structure. In this context, the level of responsibility and authority differs depending on the position they occupy, and they face new challenges and fights. Even so, the complicity between agents "underlies all existing conflicts and antagonisms"(10).
Given the democratic process of choice of nursing managers, there was a state of change in management patterns and time-space organization of each institution. This is called metamorphosis, and implies the reconfiguration of institutional management imbricated with the historical, political and social specificity of health institutions, and which probably brought a degree of satisfaction, but did not fail to generate new tensions, challenges and behaviors of its agents.

Thus, the following pass through management dynamics: legal, political and economic forms of the country and the organization itself, conceptions of institution managers regarding management paradigms, matters of authority, power relations, and legitimacy crises that generate ups and downs in a dialectical movement capable of renewing and rebuilding itself.

With regard to more general issues of society in specific sectors such as the subfield of nursing, practices are not organized and only move by an inertial and evolutionary force over time. There is a dialectic of effectiveness of these movements that are constantly updated far beyond chance, or even of any mechanical determinism. They are social and historical relations that do not make their agents innocent or guilty, but certainly put them before their possibilities of constantly remaking them.

Thinking about the nursing subfield and nurses' managerial habitus also brings us to their professional training by considering that in university life, knowledge is sought through learning new things. It is also a place of assimilation and exchange, of beliefs and values. It is a real and socially contradictory world as explained in Pierre Bourdieu's relations. In this conception, the institutionalized education system participates in the reproduction of economic, political and social conditions also crystallized in health institutions.

In the construction of the teaching system theory, Bourdieu and Passeron retake the old concept of habitus and focus that experiences lived in family relationships (denominated primary habitus) are determined by the material conditions of its class and guide future experiences ${ }^{(9)}$. However, when experiencing new situations in other social spaces, these actors can modify their practices and create new behaviors leading to the formation of a new habitus that allows people to form a guidance system in society. A long learning process is required in several types of social fields in order to reach that.

University hospitals are the social field of learning during professional training and exercise of health practices. They reproduce the institutionalized system of education in the real world, as well as the economic, political and cultural conditions. University organizations (whether as theoretical or practical teaching spaces) legitimize the power relations between doctors and nurses, and between teaching nurses and care nurses, both of which are agents of the health field or the nursing subfield. Historically, these agents have institutionally recognized differentiated authority, and in this case, nurses will occupy a certain position according to the accumulation of capital in their subsystem. Thus, by acquiring capital, nurses have the opportunity of recognition among their peers ${ }^{(7)}$.

This fact demonstrates the understanding of symbolic power and construction of reality, where the truth produced in the field is perceived and accepted as a natural truth. Thus, power agents have "the equivalent of what is obtained by force (physical or 
economic)" $[\ldots]^{(5)}$, which constitutes itself in power of symbolic violence or "a right of legitimate imposition reinforces the arbitrary power that establishes it, and which it disguises" ${ }^{\prime \prime)}$. In the symbolic fight, agents tend to impose on others their view of the social world division and of their position in this world by reproducing behaviors acquired previously in their lived experiences.

According to the above considerations, we understand the Bourdieusian sociology is a theoretical contribution to be explored in order to look at the subfield of nursing and reflect on several aspects, namely: the work process of its agents, management issues, the size of education and health organizations in this subsystem, the established power relations, and the space that nursing can achieve insofar as it accumulates cultural capital and empowers itself to confront issues that seem natural, but are permeated with symbolic violence.

\section{FINAL CONSIDERATIONS}

The principles structuring the worldviews of health field agents have roots in the sociocultural conception of professions that is reinforced by training and health institutions. In the face of acquired experience, agents tend to stick to daily practices of life that have left advantageous acquisitions by making analogies from previous situations. If they adopt certain people or groups as a reference by using the same values and norms, they will be reproducing the same attitudes and behaviors, and tend to feed the conservative force. This is the way to keep the social structure cohesive and mobilize people, classes and layers of different positions, even if antagonistic, with the purpose of immediate interests or expectations of the organization.

Thus, social practices are structured and have characteristics of the social position of those who produce them. Alliances and ruptures can be established, as well as relationships of domination and incorporation of managerial models that are not random, but emerge to respond to premises of the organizational structure. This niche is a space of fight against what seems natural, simple, and at times even dogmatic. It is also a site of symbolic violence for maintaining power.

According to reflections addressed by Bourdieu, the configuration of new attitudes is always plausible, since agents of the organizations (among which health organizations) have a margin of possibility and freedom that allows their transit in a field with the proposition of transforming the structured ordering.

This movement of going, reflecting and positioning oneself is expressed in nurses' managerial habitus. As leaders (dominant agents) in the subfield of nursing, nurses use tools that provide an effective and safe care/assistance, and better working conditions with impact on the performance and satisfaction of others (dominated agents). The working process in the subfield of nursing is complex, multifaceted, has specifics in each sphere of action, and requires skills and political-institutional insertion from its agents. These forces mobilize to break institutionalized stigmas and lead the change process from an established reality (structuring) to the desired reality (structured).

This Bourdieusian proposition allows another look at the subfield of nursing. It expands the probability that courses of transformation emerge from adverse and contradictory effects present in health and education structures. It implies another starting point: looking at oneself and reviewing oneself; looking at the field from an outside position; looking at agents, partners or adversaries. It all depends on the interest in the game and the fight one is willing to get involved in while an agent of that niche.

Bourdieu's sociology is fruitful for a reflection on the management practice by unveiling relationships and the role organizations play with their agents. It warns about the possibility of seeing changes in the nursing subfield through a new habitus by driving us to think of another paradigm, where social determinism can be corrupted by agents' critical spirit in a participant action. To this end, there must be a new look at the reality of organizations and our practices.

\section{REFERENCES}

1. Pinto L. Pierre Bourdieu e a Teoria do Mundo Social. Rio de Janeiro: FGV; 2000.

2. Bourdieu P. A casa ou o mundo invertido. In: Bourdieu P. O senso prático. 3. ed. RJ: Vozes; 2011. p. 437-462.

3. Bourdieu P. Espaço Social e Espaço Simbólico. In: Bourdieu P. Razões e práticas: sobre a teoria da ação. 11. ed. Campinas: Papirus; 2011. p. 13-27.

4. Bourdieu P. Os usos sociais da ciência: por uma sociologia clínica do campo científico. São Paulo: UNESP; 2004.

5. Bourdieu P. O poder simbólico. 15. ed. Rio de Janeiro: Bertrand do Brasil; 2011.

6. Bourdieu P. Coisas ditas. São Paulo: Brasiliense; 2011.

7. Lopes MEL, Domingos Sobrinho M, Costa SFG. Contribuições da Sociologia de Bourdieu para o Estudo do Subcampo da Enfermagem. Texto Contexto Enferm[Internet]. 2013[cited 2016 Aug 14];22(3):819-25. Available from: http://www.scielo.br/pdf/ tce/v22n3/v22n3a31.pdf

8. Quinn RE, Thompson M, Faerman SR, McGrath M. A Evolução dos Modelos Gerenciais: uma nova abordagem. In: Quinn RE, Thompson M, Faerman SR, McGrath M. Competências gerenciais: princípios e aplicações. Rio de Janeiro: Elsevier; 2003. p. 1-29.

9. Bourdieu P, Passeron JC. A reprodução: elementos para uma teoria do sistema de ensino. 5. ed. Petrópolis: Vozes; 2011.

10. Domingos Sobrinho M. Campo científico e interdisciplinaridade. In: Guimarães FR, Fernandes A, Brasileiro MCE, (Orgs.). O fio que une as pedras: a pesquisa interdisciplinar na pós-graduação. São Paulo: Biruta; 2002. p. 49-58. 